\title{
Öğretmen Algıları Bağlamında Ortaokullarda Örgütsel Sessizlik ${ }^{1}$
}

\author{
DOI: 10.26466/opus.725872 \\ * \\ Soner Doğan* ${ }^{*}$ Esma Karahan Çidem** \\ *Doç.Dr, Sivas Cumhuriyet Üniversitesi \\ E-Posta: snr312@gmail.com \\ ORCID: $\underline{0000-0003-2013-3348}$ \\ ** Öğretmen, Milli Ĕ̆itim Bakanlığı \\ E-Posta: esma.karahan@hotmail.com \\ ORCID: $\underline{0000-0003-0275-6277}$
}

\begin{abstract}
Öz
Bu araştırmada ortaokullarda görev yapan öğretmenlerin örgütsel sessizlik algılarının ortaya konması ve bu algının demografik değiş̧kenlere göre farklllık gösterip göstermediğinin tespit edilmesi amaçlanmıştır. Araştırmanın evrenini Sivas il merkezinde yer alan tüm ortaokullar oluşturmaktadır. Kolay ulaşılabilir örnekleme yöntemiyle bu okullarda görev yapan 300 öğretmen örneklem grubu olarak belirlenmştir. Araştırma verileri üç boyut ve 30 maddeden oluşan örgütsel sessizlik ölçeği ile toplanmıştır. Elde edilen veriler SPSS 22 paket programı ile analiz edilmiştir. Verilerin değerlendirilmesinde, tanımlayıcı istatistiksel yöntemlerin yanında, bağımsız örneklerde $t$ testi ve tek yönlü ANOVA analizlerinden faydalanılmıştır. Analiz sonucunda katılımcıların örgütsel sessizlik algılarının ortalamanın üstünde olduğu belirlenmiştir. Çalışmada, genel olarak örgütsel sessizliğin alt boyutlar ile öğretmenlerin cinsiyet, medeni durum, branş, kıdem yıl ve mevcut okuldaki çalışma süresi değişkenleri arasında anlamlı bir farklılık bulunmamıştır. Sadece öğretmen boyutu ile katılımciların branş değişkeni arasında anlamlı bir farklılık bulunmuştur. Araştırmanın sonunda bulgulara dayanılarak öneriler sunulmuştur.Bu bağlamda okul ortamında yaşanan örgütsel sessizlik davranışının önlenmesinde öğretmen ve yöneticilere düşen görevler olduğu söylenebilir.
\end{abstract}

Anahtar Kelimeler: Sessizlik, örgütsel sessizlik, ortaokul, öğretmen

\footnotetext{
${ }^{1}$ Bu çalışma Sivas Cumhuriyet Üniversitesi Eğitim Bilimleri Enstitüsü'nde tamamlanan yüksek lisans tezine dayalı olarak hazırlanmıştır.
} 
ISSN: 2528-9527

E-ISSN : 2528-9535

Yıl Year: 11

Cilt Volume: 17

Sayı Issue: 35

Mart March 2021

Makalenin Gelis Tarihi Received Date. 23/04/2020 Makalenin Kabul Tarihi Accepted Date. 26/03/2021

\title{
Organizational Silence In Secondary Schools In The Context Of Teacher Perceptions
}

\begin{abstract}
The present study aimed to present teachers' perception in secondary schools on organizational silence and to identify whether this perception varied across demographic variables. The study group is composed of all secondary schools in the city center of Sivas. 300 teachers working in these schools were identified as the sample group using the convenience sampling method. The research data were collected using the Organizational Silence Scale composed of 3 dimensions and 30 items. The collected data were analyzed using SPSS 22 package program. In data evaluation, in addition to descriptive statistical methods, the independent samples $t$-test and one-way ANOVA analyses were used. The analysis results demonstrated that participants' perception on organizational silence was above average. In the study, no significant difference was found between the subscales of organizational silence and variables such as teachers' gender, marital status, branch, year of seniority and working year in the current school. A significant difference was found only between the teacher subscale and the branch variable. Suggestions were provided at the end of the study, based on findings. In this context, it can be said that teachers and administrators have duties in preventing the organizational silence behavior experienced in the school environment.
\end{abstract}

Keywords: Silence, organizational silence, secondary school, teacher 


\section{Giriş}

Günümüzde örgütlerin varlıklarını başarıyla sürdürebilmeleri için üretken ve yeniliklere açık olmaları önem taşımaktadır. Bir örgütün başarısını etkileyen en önemli faktör çalışanların örgüt yararına olan çalışmalarıdır. Çalışanların yetenekleri, tecrübeleri, duygu ve düşünceleri, işlerine olan bağlllıkları örgütün verimliliği açısından önem taşımaktadır. Bundan dolayı örgütlerin çalışanlarının fikirlerine, beklenti ve önerilerine değer vermeleri, onların örgütte kendilerini göstermelerine fursat vermeleri gerekmektedir. Bu bağlamda örgütlerde çalışanların sessiz kalmamaları, örgütün tüm süreçlerinde kendilerini ifade etmeleri önem kazanmaktadır. Ancak değişik nedenlere bağlı olarak çalışanlar zaman zaman örgütsel sessizliğe bürünmekte ve örgüte katkı sağlayamamaktadır.

Sessizlik kavramı, sessiz olma durumu, sükût, ortalıkta gürültü olmaması halidir (TDK, 2005). Sessizlik ve konuşma kavramları sadece birbirlerinin zıt anlamlıları olarak değerlendirilmemelidir. Sessizlik hali bir amacı olan ve çeşitli anlamlar taşıyan stratejik bir tutumdur. Çalışanlar sessizliği tercih ederek yöneticilerine çeşitli mesajlar vermek isteyebilirler (Yaman ve Ruçlar, 2014). Örgütsel sessizlik, kurum çalışanlarının kurumsal katkı sağlayacak çalışmalara katılmalarına engel olmakta ve çalışanlarda isteksizlik oluşturmaktadır (Dyne, Ang ve Botero, 2003). Örgütsel sessizlik, örgüt çalışanlar1nın işleri veya kurumlarına ilişkin fikir, bilgi ve düşüncelerini bilinçli olarak gizlemesi örgütü ilgilendiren konularda gerçek düşüncelerini saklaması olarak tanımlanabilir (Morrison ve Milliken, 2000). Örgütsel anlamda sessizlik tehdit, korku, geri çekilme, savunma mekanizmaları gibi çeşitli psikososyal etkenleri içermektedir (Pinder ve Harlos, 2001).

Örgütsel sessizlik bir örgütte ortaya çkan önemli sorunlara karşı sessiz kalınarak verilen tepkiler olarak da ifade edilebilir (Henriksen ve Dayton, 2006). Örgütsel ses, örgütte güçlü bir değişim için önemli bir kaynak iken çalışanlar bazı durumlarda konuşmak istemezler. Birçok akademik çalışmada örgütün gelişimi için alttan üste doğru iletişimin önemi ve kararların etkin olabilmesi için farklı görüşlerin gerekliliği vurgulanırken, birçok çalışan örgütle alakalı konular ve yaşanan sorunlarla ilgili yukarı doğru iletişim kuramamaktadırlar (Çakıcı, 2008).

Çalışanlar bazı durumlarda konuşmayı seçerken, bazı durumlarda sessiz kalmayı seçerler (Milliken, Morrison ve Hewlin, 2003). Sessizlik bir çok fak- 
törden etkilenen bir davranış olduğu için çalışanların da sessiz kalmalarının bir takım nedenleri bulunmaktadır (Dyne, Ang ve Botero, 2003). Sessizlik kararı bir anda alınan bir karar değildir, bir süreç neticesinde bu davranış sergilenir (Karadal, 2011). Örgütlerde neden sessiz kalındığına dair yapılan araştırmalar neticesinde sessizliğin bireysel, yönetsel ve örgütsel sebeplerden kaynaklandığı ortaya çıkarılmıştır (Erol ve Köroğlu, 2013; Bayram, 2010). Bu sonuçlar dikkate alındığında örgütsel sessizliğin tek bir nedene bağlanamayacağı, çeşitli faktörlerden kaynaklanan birçok sebebi olduğu anlaşılmaktadır (Erigüç, vd., 2014).

Örgütsel sessizlik davranışının temellerini açiklamaya çalışan araştırmacılar bu konuyla ilgili çeşitli kuramlar ortaya atmışlardır. Bu kuramlardan "Beklenti Kuramına" göre bireyler davranışlarının neticelerine göre sessizlik tepkisi geliştirirken, "Sessizlik Sarmalında" izole edilme endişesi bireyleri sessizliğe itmektedir. Kendine Uyarlama kuramında ise çalışanlar diğer çalışanların tepkileri doğrultusunda sessiz kalırlar (Gül ve Özcan, 2011). Planlı Davranış Kuramı bireylerin davranışı gerçekleştirmeden önce kendi içinde çeşitli hesaplar yaparak sessizliği seçtiğini vurgulamaktadır (Mercan, 2015). Fayda maliyet analizinde ise çalışanlar konuşmanın veya susmanın sağlayacağ fayda veya zarara göre sessizlik davranışında bulunurlar (Çavuş, Develi ve Sarığlu, 2015).

Örgütsel sessizlik çalışanların değersizlik hissi yaşamasına sebep olmaktadır. Çalışanlar değersizlik hissinin neticesinde çalışma arkadaşlarına ya da yöneticilerine karşı kızgın ve öfkeli duygular besleyebilir. Sessizlik sorunu çözülmediği takdirde çalışanların birbirlerine beslediği olumsuz duygular giderek artacaktır. Bunun neticesinde çalışanlar örgüt yararından çok sadece kendilerini düşünen bir tavır sergileyeceklerdir. Sessizlik iklimi çalışanların enerjisi, örgütsel verimlilik, iş doyumu gibi çeşitli özelliklerini olumsuz yönde etkileyecektir (Alparslan ve Kayalar, 2012). Zamanla sonlanmayan ve artan sessizlik çalışanın örgüte olan güven duygusunun yıkılmasına, örgütsel güvensizliğin oluşmasına neden olmaktadır. Güvensizlik hissi ise çalışanı daha fazla sessizlik davranışına sürüklemektedir (Çakıcı, 2008). Örgütsel sessizlik, girdisi ve çıktısı insan olan eğitim kurumlarını da olumsuz etkilemektedir.

Okullar bilginin üretildiği, güncellendiği ve geliştirildiği yapılardır. Toplum için gerekli olan insan gücünü yetiştirmek okulların görevidir. Her sosyal örgütün en temel ögesi olan insan unsurunu yetiştiren kurumların 
sürekli gelişim ve değişime açık olması gerekir. Değişimin ve gelişimin önünde önemli bir engel oluşturan örgütsel sessizlik konusunun okullarda araştırılması ve bu duruma çözüm önerileri getirilmesi önem taşımaktadır (Bayram, 2010).

Literatürde eğitim kurumlarında yapılan örgütsel sessizlik çalışmalarına rastlanmaktadır. Çakıcı (2007) akademisyenlerin \%70'inin sessiz kalmayı tercih ettiklerini ortaya çıkarmıştır. Sessizliği seçme sebeplerinin başında ise yönetimsel ve örgütsel sebepler olduğu ifade edilmiştir. Kahveci (2010) ilköğretim okullarında görev yapan öğretmenlerin ve yöneticilerin yaşadıkları problemleri rahat bir şekilde dışa vurmadıkları ve sessiz kaldıkları; Bayram (2010) üniversitelerde örgütsel sessizliğin yaşandığını, yönetimde görev almayan akademik çalışanlarda sessizliğin daha fazla olduğu; Kahveci ve Demirtaş (2013) öğretmenlerin genellikle düşüncelerini ifade etmediklerini, sessizlik yaşadıkları; Şahin (2016) ilkokul öğretmenlerinin örgütsel sessizlik düzeyini ortanın altında olduğu; Dal ve Baskan (2018) öğretmenlerin örgütsel sessizlik seviyelerinin "orta" düzeyde olduğu; Konakcı Göven (2018) öğretmenlerin örgütsel sessizlik düzeyleri orta seviyenin biraz üstünde olduğu; Bağ ve Ekinci (2018) öğretim elemanları etik olmayan uygulamalar, yönetimsel uygulamalar ve akademik yapı ve işleyiş konularıla ilgili sorunlarda ciddi ölçüde sessizlik davranışı sergiledikleri; Gencer (2018) okul müdürlerinin kullandığı güç merkezi oluşturma oyunları ile öğretmenlerin örgütsel sessizlikleri ve örgütsel sosyalleşmeleri arasında orta seviye anlamlı pozitif ilişki bulunduğu sonucuna ulaşmışlardır.

Uluslararası literatüre bakıldığında ise Bowen ve Blackmon (2003) öğretmenlerin çalışma arkadaşlarından gelebilecek olumsuz eleştiriler veya dışlanma korkusunun etkisiyle sessizlik davranışı sergiledikleri; Morrison ve Milliken (2000) iş görenlerdeki korku boyutunun sessizlik davranışına sebep olduğu; Pinder ve Harlos (2001) çalışanların örgütte adaletsizlik hissetmelerinin örgütsel sessizliğe neden olduğu; Vakola ve Bouradas (2005) sessizlik ile örgüte bağlılık arasında anlamlı ilişki bulunduğu; Henriksen ve Dayton'un (2006) örgütsel sessizliğe neden olan faktörlerin bireysel, örgütsel ve sosyal boyutta olduğu; Fapohunda (2016) örgütsel sessizliğin göstergelerinin başında yönetimsel inançlar, örgüt içi etkinlikler, sorun çıaran kişi olarak algılanma endişesi ve son olarak itibara zarar verme kaygısı olduğunu sonucuna ulaşmıştır. 
Araştırma ortaokullarda görev yapan öğretmenlerin örgütsel sessizliğe ilişkin algılarını ölçmeyi amaçlamaktadır. Örgütsel sessizliğin örgütsel gelişimin ve yeniliğin önünde önemli bir engel olduğu, aynı zamanda örgüt içi sorunların çözülememesine ve çalışanların örgütsel bağlılığın azalmasına neden olduğu söylenebilir. Bu bakımdan bu çalışma araştırmaya katılan öğretmenlerin örgütsel sessizlik algı düzeylerinin belirlenmesi ve sessizliğin nedenlerinin ortaya konulması bu sorunun çözümüne katkı sağlaması açısindan önemlidir.

\section{Yöntem}

Bu bölümde araştırmanın modeli, evreni ve örneklemi, veri toplama aracı ve verilerin analizinde kullanılan teknikler ele alınmıştır. Çalışma 2019 yılı içerisinde tamamlandığı için geriye dönük etik kurul kararı alınamamıştır.

\section{Araştırma Modeli}

Araştırmada bağımlı ve bağımsız değişkenler arasındaki ilişki incelenmiştir. Bu ilişkiyi belirlemek için ilişkisel tarama modeli kullanılmıştır. İlişkisel tarama modeli iki ya da daha fazla sayıdaki değişken arasında birlikte değişim olup olmadığını ve birlikte değişim varsa bu değişimin derecesini tespit etmeyi amaçlayan bir araştırma yöntemidir (Karasar, 2013). Bu çalışmada bağımsız değişken katılımcıların demografik özellikleri, bağımlı değişken ise örgütsel sessizlik ölçeğinin alt faktörleridir. Katılımcllara ait demografik bilgiler cinsiyet, yaş, medeni durum, branş, kıdem yılı ve halihazırda çalıştığı okuldaki çalışma süresinden oluşmaktadır. Örgütsel sessizlik ise yönetici (yönetsel), öğretmen (bireysel) ve ortam (örgütsel) olmak üzere üç faktörden oluşmaktadır.

\section{Evren ve Örneklem}

Araştırmanın evreni Sivas il merkezindeki Milli Eğitim Bakanlığı'na bağlı ortaokullarda görev yapan öğretmenlerden oluşmaktadır. Sivas il merkezinde faaliyet gösteren 79 ortaokul bulunmaktadır (https://sivas.meb.gov.tr/). Kolay ulaşllabilir örnekleme yöntemiyle bu okullarda görev yapan 300 öğretmene anket formu ulaştırılmış ve değerlendirilebilir 252 ölçek elde edilmiştir. Katılımcıların demografik özellikleri Tablo 1'de görüldüğü gibidir. 
Tablo 1. Katılımcıların demografik özellikleri

\begin{tabular}{|c|c|c|}
\hline Demografik Özellik & Frekans & Yüzde (\%) \\
\hline \multicolumn{3}{|l|}{ Cinsiyet } \\
\hline Kadın & 116 & 46,0 \\
\hline Erkek & 136 & 54,0 \\
\hline \multicolumn{3}{|l|}{ Medeni Durum } \\
\hline Evli & 218 & 86,5 \\
\hline Bekar & 34 & 13,5 \\
\hline \multicolumn{3}{|l|}{ Branş } \\
\hline Türkçe & 48 & 19,0 \\
\hline Matematik & 44 & 17,5 \\
\hline Fen ve Teknoloji & 37 & 14,7 \\
\hline Sosyal Bilgiler & 22 & 8,7 \\
\hline İngilizce & 27 & 10,7 \\
\hline Din Kültürü ve Ahlak Bilgisi & 22 & 8,7 \\
\hline Görsel Sanatlar & 10 & 4,0 \\
\hline Müzik & 6 & 2,4 \\
\hline Beden Eğitimi & 15 & 6,0 \\
\hline Teknoloji ve Tasarım & 13 & 5,2 \\
\hline Bilişim Teknolojileri & 3 & 1,2 \\
\hline Rehber & 5 & 2,0 \\
\hline \multicolumn{3}{|l|}{ Kidem Yilı } \\
\hline $1-8$ yll & 85 & 33,7 \\
\hline 9-17 yll & 121 & 48,0 \\
\hline 18 yıl ve üzeri & 46 & 18,3 \\
\hline \multicolumn{3}{|c|}{ Mevcut Okuldaki Çalışma Süresi } \\
\hline $1-8$ yll & 222 & 88,1 \\
\hline $9-17$ yil & 24 & 9,5 \\
\hline 18 yll ve üzeri & 6 & 2,4 \\
\hline Toplam & 252 & 100 \\
\hline
\end{tabular}

Tablo 1'e bakıldığında katılımcıların \%46'sının kadın, \%54'ünün erkek olduğu görülmektedir. Yaş aralıkları dikkate alındığında katılımcıların \%29,8'i 30-34 yaş aralığındadır, \%3,2'sinin yaşı 24'ten azdır. En çok rastlanan branş \%19 ile Türkçe iken, en rastlanan branş ise \%1,2 ile Bilişim Teknolojileri olmuştur. Katılımcıların \%48'i 9 ila 17 yıl, \%18,3'ü ise 18 ve daha fazla yıldır öğretmenlik yapmaktadır. Katılımcıların \%88,1'i 1 ila 8 yıldır mevcut okulunda çalışırken, 18 ve daha fazla yıl çalışanların oranı $\% 2,4^{\prime}$ tür.

\section{Veri Toplama Araci}

Araştırmada birincil veri toplama tekniklerinden anket yöntemi kullanılmıştır. Anket araştırmacının önceden belirlediği sırada ve yapıda olan sorulara katılımcının cevap vermesini istediği veri toplama tekniğidir (Uzgören, 2012). Bu çalışmada kullanılan anket iki bölümden oluşmaktadır. İlk bö- 
lümde katılımclara ait demografik bilgiler istenmiştir. İkinci bölümde ise örgütsel sessizlik ölçeği yer almaktadır. Kahveci ve Demirtaş (2013) tarafından geliştirilen bu ölçekte 30 madde bulunmaktadır. Ölçekte tüm test maddelerinin güvenirliği için Cronbach Alpha, 883 hesaplanmıştır. Yapılan faktör analizi sonucunda 30 madde üç boyuttan oluşan bir ölçek elde edilmiştir. Faktörler toplam varyansın \%41,537'sini açıklamaktadır. Kaiser-MeyerOlkin (KMO) Örnekleme Yeterlik Ölçüsü ,6'nın üstünde değer verdiğinden (,799) yeterli görülmüştür. Ayrıca Bartlett Testi=1727,568 olarak hesaplanmıştır. Ölçekte, örgütsel sessizliğe neden olan yönetsel nedenleri ölçmek amaciyla 13 maddeden oluşan yönetici boyutu, bireysel nedenleri ölçmek amaciyla 11 maddeden oluşan öğretmen boyutu ve örgütsel nedenleri ölçmek amacıyla 6 maddeden oluşan ortam boyutu yer almaktadır. Ölçek Likert tipinde hazırlanmış olup katılımcılardan önermeleri Tamamen Katılıyorum (5), Katılıyorum (4), Orta Düzeyde Katılıyorum (3), Katılmıyorum (2), Hiç Katılmıyorum (1) derecelerinde cevaplamaları istenmiştir.

Ayrıca bu araştırma kapsamında, kullanılan ölçekte yer alan ifadelerin kendi aralarında tutarlı olup olmadıklarını belirlemek amacıyla güvenirlilik analizi yapılmış ve Cronbach's Alpha değerleri hesaplanmıştır. Hesaplanan alfa katsayısı ile bir ölçeğin güvenirlilik düzeyi aşağıda yer alan aralıklara göre yorumlanabilir (Kalayc1, 2008):
$0<\quad$ Alfa $<0,40$ ise ölçek güvenilir değildir.
$0,40<$ Alfa $<0,60$ ise ölçeğin güvenirliliği düşüktür.
$0,60 \quad<\quad$ Alfa $\quad<0,80$ ise ölçek oldukça güvenilirdir.
$0,80<\quad$ Alfa $<1,00$ ise ölçek yüksek düzeyde güvenilirdir.

Bu çalışmada kullanılan ölçeğin tamamına ve alt faktörlere ilişkin yapılan güvenirlilik analizi sonuçları Tablo 2' de görüldüğ̈̈ gibidir.

Tablo 2. Ölçek güvenirlilik analizi

\begin{tabular}{lll}
\hline Ölçek Adı & Madde Sayısı & Cronbach's Alpha Değeri \\
\hline Örgütsel Sessizlik & 30 & 0,88 \\
\hline Alt Faktörler & & \\
Yönetici & 13 & 0,74 \\
Öğretmen & 11 & 0,67 \\
Ortam & 6 & 0,63 \\
\hline
\end{tabular}

Tablo 2'de yer alan veriler incelendiğinde örgütsel sessizlik ölçeğinin tamamı için Cronbach's Alpha değeri 0,88 olarak hesaplanmıştır. Bu sonuç 
ölçeğin yüksek düzeyde güvenilir $(0,80<\mathrm{Alfa}<1,00)$ olduğunu göstermektedir. Alt ölçeklerin Cronbach's Alpha değerleri ise yönetici boyutu için 0,74, öğretmen boyutu için 0,67 ve ortam boyutu için 0,63 olarak hesaplanmıştır. Elde edilen bu sonuçlar bu faktörlerin oldukça güvenilir $(0,60<\mathrm{Alfa}<0,80)$ olduğunu göstermektedir.

\section{Verilerin Analizi}

Verilerin analiz edilmesinde SPSS 22 programından yararlanılmıştır. Öncelikle demografik özelliklerin frekans ve yüzde dağılımları hesaplanmıştır. Ölçeğin güvenilirliği için Cronbach's Alpha değeri hesaplanmıştır.

Ölçekte yer alan üç boyuttaki faktörlerin demografik özelliklere göre farklılık gösterip göstermediğinin belirlenmesinde uygulanacak analiz yönteminin seçimi için öncelikle verilerin normal dağılım olup olmadığını belirlemek amaciyla Kolmogorov-Simirnov ve Shapiro Wilk testleri yapılmalıdır. Araştırmadaki gözlem sayısı 29'dan az olduğunda normal dağılımı belirlemek için Shapiro Wilk, fazla olduğunda ise Kolmogorov-Simirnov testi uygulanmaktadır (Kalayc1, 2008). Bu araştırmada gözlem sayısı 29'dan fazla olduğu için Kolmogorov-Simirnov testi uygulanmıştır. Test sonucunda eğer anlamlılık düzeyi 0,05 'ten büyük olursa normal dağılım olduğu sonucuna varılır. Aynı zamanda verilerin çarpıklık ve basıklık katsayılarının +1 ile -1 arasında olması da normal dağılım olduğunu göstermektedir (Pallant, 2001). Araştırma verileri için yapılan analiz sonucu elde edilen sonuçlar Tablo 3'te görüldüğ̈̈ gibidir.

Tablo 3. Normal dağılım analiz sonuçları

\begin{tabular}{llllllll}
\hline \multirow{2}{*}{ Faktör } & \multicolumn{2}{l}{ Kolmogorov-Smirnov } & \multirow{2}{*}{ Çarpıklık } & \multicolumn{3}{c}{ Basıklık } \\
\cline { 2 - 5 } & Statistic & df & Sig. & & & \\
\hline Yönetici & 0,082 & 252 & 0,000 & $-0,345$ & 0,153 & $-0,064$ & 0,306 \\
\hline Öğretmen & 0,048 & 252 & 0,200 & $-0,099$ & 0,153 & $-0,044$ & 0,306 \\
\hline Ortam & 0,101 & 252 & 0,000 & 0,130 & 0,153 & 0,773 & 0,306 \\
\hline
\end{tabular}

a. Lilliefors Significance Correction

Tablo 3'te yer alan sonuçlara göre Kolmogorov-Smirnov testi ile anlaml1lık düzeyi öğretmen boyutu için 0,05 'ten büyük, yönetici ve ortam boyutu için 0,05 'ten küçük hesaplanmıştır. Bu sonuç öğretmen boyutunda yer alan verilerin normal dağıldığını, yönetici ve ortam boyutu için normal dağılım olmadığını göstermektedir. Bu durumda bu iki boyutun çarpıklık ve basıklık değerlerine bakılmıştır. Her iki faktörde de çarpıklık (yönetici - 
0,345/0,153 ve ortam 0,130/0,153) ve baskklık (yönetici -0,064/0,306 ve ortam $0,773 / 0,306)$ değerleri +1 ile -1 arasında olduğu için normal dağllım olduğu belirlenmiştir.

Aynı zamanda araştırmada yer alan alt ölçeklerin demografik özelliklere göre farklılıklarının incelenmesinden önce bağımlı değişkendeki varyansın bağımsız değişkendeki gruplara homojen olarak dağılıp dağılmadığını yani normal dağılım olup olmadığını belirlemek üzere yapılacak testlerden biri levene testidir. $\mathrm{Bu}$ analiz sonucu elde edile anlamlılık değeri (p) 0,05'ten büyük ise dağılım normal kabul edilir (Gamgam ve Altunkaynak, 2017). Araştırma verilerine yapılan Levene Testi sonucu tüm demografik özellikler için normal dağılım olduğu tespit edilmiştir. Teste ilişkin bulgular dördüncü bölümde verilmiştir.

Veriler normal dağılım gösterdiği için analizde parametrik testler uygulanmıştır. Demografik özellikler ile ölçek faktörleri arasındaki ilişkinin belirlenmesi amaciyla cinsiyet ve medeni durum için $t$ testi, yaş, branş, kıdem yılı ve mevcut okuldaki çalışma süreleri için ANOVA testi yapılmıştır.

\section{Bulgular}

$\mathrm{Bu}$ bölümde araştırma problemlerine ilişkin elde edilen analiz sonuçları verilmiştir. Öncelikle ölçeğe ilişkin genel dağılım, sonrasında katılımcıların demografik özelliklerine göre dağglımlara yer verilmiştir.

\section{Örgütsel Sessizliğe İlişkin Genel Dă̆ılım}

Araştırmada öğretmenlerin örgütsel sessizlik algısının belirlenmesi amacıyla kullanılan ve 30 maddeden oluşan örgütsel sessizlik ölçeğine ilişkin sonuçlar Tablo 4'e görüldüğü gibidir.

Tablo 4. Örgütsel sessizlik ölçeğine ilişkin genel dağılım

\begin{tabular}{lll}
\hline Ölçek & Ortalama $(\bar{X})$ & Standart Sapma (S) \\
\hline Örgütsel Sessizlik & 3,32 & 0,47 \\
\hline Yönetici Ölçeği & 3,73 & 0,55 \\
\hline Öğretmen Ölçeği & 3,03 & 0,59 \\
\hline Ortam Ölçeği & 2,98 & 0,54 \\
\hline
\end{tabular}

Tablo 4'e yer alan sonuçlar incelendiğinde örgütsel sessizlik ölçeğinin ortalaması 3,32 olarak hesaplanmıştır. Bu sonuca göre araştırmaya katılan öğretmenlerin örgütsel sessizlik düzeyleri ortalamanın üzerindedir. Stan- 
dart sapmanın 0,47 olarak çıkması da katılımcıların cevaplarının birbirine yakın olduğunu gösterir. Okullardaki işleyişe ilişkin konularda öğretmenlerin fikir beyan etmekten kaçınıyor olmaları olumsuz bir durum olarak değerlendirilebilir.

\section{Katılımcılarn Demografik Özelliklerine Göre Örgütsel Sessizlikte Yönetici boyutu Hakkındaki Görüşleri}

Araştırma ölçeğinde yer alan örgütsel sessizliğin yönetici boyutu 13 maddeyi kapsamaktadır. Bu maddelerin frekans, ortalama ve standart sapma dağglımları Tablo 5’de görüldüŭğ gibidir.

\section{Tablo 5. Yönetici boyutuna ilişkin ortalamalar ve standart sapmalar}

\begin{tabular}{llrc}
\hline No & Madde & $\bar{X}$ & $\mathrm{~S}$ \\
\hline \multirow{3}{*}{3} & $\begin{array}{l}\text { Öğretmenlerin duygu ve düşüncelerini dile getirmeleri, örgütsel } \\
\text { öğrenmeyi ve gelişmeyi destekler. }\end{array}$ & 4,01 & 0,75 \\
\hline 4 & Okulumuzda farklı bakış açlları olduğunda isabetli karar verme ihtimali yükselir. & 3,81 & 0,99 \\
\hline 6 & Öğretmenlerin duygu ve düşüncelerini ifade edememesi onları okuldan soğutur & 3,73 & 0,99 \\
\hline 7 & Öğretmenler problemlerini dile getiremediklerinde performansları düşer. & 3,79 & 0,91 \\
\hline 10 & Öğretmenlerin içsel memnuniyetsizliği endişe ve stresi tetikler. & 3,93 & 0,85 \\
\hline 18 & Okul yöneticilerinin “En iyi ben bilirim” tavrı, öğretmenlerin üzerinde olumsuz bir etki yaratır. 3,65 & 1,01 \\
\hline \multirow{2}{*}{19} & $\begin{array}{l}\text { Okul yöneticilerinin performanslarının düşük olması, öğretmenlerin } \\
\text { sorunlarını dile getirmesini engeller. }\end{array}$ & 3,26 & 1,04 \\
\hline 20 & $\begin{array}{l}\text { Öğretmenlerin okul yöneticilerine güven duymamaları, duygu ve } \\
\text { düşüncelerini dile getirmelerine engel olur. }\end{array}$ & 3,58 & 1,02 \\
\hline 21 & $\begin{array}{l}\text { Okuldaki sorunların dile getirilmemesi, hem öğretmenlerin } \\
\text { hem de okulun gelişimini olumsuz etkiler }\end{array}$ & 4,05 & 0,91 \\
\hline 22 & $\begin{array}{l}\text { Okul yöneticilerinin içtenliği ve dürüstlü̆ğü, ö̆retmenlerin kendi } \\
\text { düşüncelerini dile getirmelerine teşvik eder. }\end{array}$ & 4,13 & 0,89 \\
\hline 23 & Okullarda sorunların dile getirilmemesinde kilit rol okul yöneticilerinindir. & 3,56 & 0,97 \\
\hline 24 & $\begin{array}{l}\text { Okul yöneticilerinin, öğretmenleri hakkında önyargılı olması } \\
\text { ögretmenlerin kendi duygu ve düşüncelerini dile getirmelerine engel olur. }\end{array}$ & 3,55 & 0,95 \\
\hline 28 & $\begin{array}{l}\text { Yöneticiler ve öğretmenler arasında açı iletişimin olmaması, } \\
\text { öğretmenlerin duygularını ifade etmemesine neden olur. }\end{array}$ & 3,55 & 0,93 \\
\hline & Genel Ortalama & 3,73 & 0,55 \\
\hline
\end{tabular}

Tablo 5'e bakıldığında yönetici boyutunun genel ortalamasının 3,73 ve standart sapmanın 0,55 olduğu görülmektedir. Bu sonuca göre katılımcıların yönetici boyutuna bağlı örgütsel sessizlik algı düzeylerinin ortalamanın üzerinde olduğu görülmektedir.

Bu boyutu oluşturan maddelerin tek tek ortalamaları ele alındığında en düşük ortalamaya sahip olan madde 19. maddedir. Bu maddenin ortalaması 3,26 olarak hesaplanmıştır. Yönetici boyutu içinde yöneticinin performansı- 
nın düşük olması öğretmenlerin örgütsel sessizliği üzerinde en az etkiye sahip olan durumdur. En yüksek ortalamaya sahip madde ise 4,13 ile 22 . maddedir. Öğretmenler yöneticilerin içten ve dürüst davranmaları halinde düşüncelerini çok rahat dile getirebilecektir. Ortalaması 4,05 olan 21 madde ele alındığında öğretmenler sorunları dile getirememeleri halinde hem kendi gelişimlerinin hem de okulun gelişiminin olumsuz etkileneceği düşünmektedirler.

Yönetici boyutu ile cinsiyet değişkeni: Katılımclların cinsiyet değişkeni ile örgütsel sessizliğin yönetici boyutu arasındaki ilişkiye ilişkin analiz sonuçlar1 Tablo 6'da görüldüğü gibidir.

Tablo 6. Yönetici boyutu ile cinsiyet değişkeni arasındaki ilişki

\begin{tabular}{llllll}
\hline Cinsiyet & $\mathrm{N}$ & $\bar{X}$ & $\mathrm{~S}$ & $\mathrm{t}$ & $\mathrm{p}$ \\
\hline Kadın & 116 & 3,76 & 0,52 & \multirow{2}{*}{0,871} & \multirow{2}{*}{0,38} \\
\hline Erkek & 136 & 3,70 & 0,57 & & \\
\hline
\end{tabular}

Tablo 6'da yer alan sonuçlara göre katılımciların cinsiyet değişkeni ile örgütsel sessizliğin yönetici boyutu arasında 0,05 anlamlılık düzeyinde anlamlı bir farklılık $(\mathrm{t}=0,871 ; \mathrm{p}=0,38)$ bulunmamaktadır. Gerek kadın gerek erkek katılımcıların yönetici boyutuna ilişkin algıları benzerlik göstermektedir.

Yönetici boyutu ile medeni durum değişkeni: Katılımcların medeni durum değişkeni ile örgütsel sessizliğin yönetici boyutu arasındaki ilişkiye ilişkin analiz sonuçları Tablo 7'de görüldüğü gibidir.

Tablo7. Yönetici boyutu ile medeni durum değişkeni arasındaki ilişki

\begin{tabular}{llllll}
\hline Cinsiyet & $\mathrm{N}$ & $\bar{X}$ & $\mathrm{~S}$ & $\mathrm{t}$ & $\mathrm{p}$ \\
\hline Evli & 218 & 3,74 & 0,54 & \multirow{2}{*}{0,309} & \multirow{2}{*}{0,75} \\
\hline Bekâr & 34 & 3,70 & 0,64 & & \\
\hline
\end{tabular}

Tablo 7'de yer alan sonuçlara göre katılımclların medeni durum değişkeni ile örgütsel sessizliğin yönetici boyutu arasında 0,05 anlamlılık düzeyinde anlamlı bir farklılık $(\mathrm{t}=0,309 ; \mathrm{p}=0,75)$ bulunmamaktadır. Yani katılımcıları medeni durumu fark etmeksizin yönetici boyutuna ilişkin algıları benzerlik göstermektedir. 
Yönetici boyutu ile branş değişkeni: Katılımcıların branş değişkeni ile örgütsel sessizliğin yönetici boyutu arasındaki ilişkiye ilişkin analiz sonuçları Tablo 8' de görüldüğü gibidir.

Tablo 8. Yönetici boyutu ile branş değişkeni arasındaki ilişki

\begin{tabular}{|c|c|c|c|c|c|c|c|c|}
\hline Alt Boyut & $\bar{X}$ & $S$ & $\begin{array}{l}\text { Varyansin } \\
\text { Kaynağ1 }\end{array}$ & $\begin{array}{l}\text { Kareler } \\
\text { Toplamı }\end{array}$ & $\mathrm{sd}$ & $\begin{array}{l}\text { Kareler } \\
\text { Ort. }\end{array}$ & $\mathrm{F}$ & $\mathrm{p}$ \\
\hline Türkçe & 3,90 & 0,51 & \multirow{4}{*}{$\begin{array}{l}\text { Gruplar } \\
\text { Arası }\end{array}$} & \multirow{4}{*}{5,36} & \multirow{4}{*}{11} & \multirow{4}{*}{0,48} & \multirow{12}{*}{1,624} & \multirow{12}{*}{0,09} \\
\hline Matematik & 3,65 & 0,47 & & & & & & \\
\hline Fen ve Teknoloji & 3,83 & 0,61 & & & & & & \\
\hline Sosyal Bilgiler & 3,69 & 0,53 & & & & & & \\
\hline İngilizce & 3,71 & 0,60 & \multirow{4}{*}{ Grup İçi } & \multirow{4}{*}{72,05} & \multirow{4}{*}{240} & \multirow{4}{*}{0,30} & & \\
\hline Din Kültürü ve Ahlak & 3,55 & 0,58 & & & & & & \\
\hline Görsel Sanatlar & 3,90 & 0,52 & & & & & & \\
\hline Müzik & 4,00 & 0,24 & & & & & & \\
\hline Beden Eğitimi & 3,38 & 0,59 & \multirow{4}{*}{ Toplam } & \multirow{4}{*}{77,42} & \multirow{4}{*}{251} & & & \\
\hline Teknoloji ve Tasarım & 3,67 & 0,62 & & & & & & \\
\hline Bilişim Teknolojileri & 3,89 & 0,32 & & & & & & \\
\hline Rehber & 3,72 & 0,42 & & & & & & \\
\hline
\end{tabular}

Tablo 8'de yer alan sonuçlara göre 0,05 anlamlılık düzeyinde katılımcıların branş değişkeni ile örgütsel sessizliğin yönetici boyutu arasında anlamlı bir farklılık ( $\mathrm{F}=1,624 ; \mathrm{p}=0,09)$ bulunmamaktadır. Yani katılımcıların branşları fark etmeksizin yönetici boyutuna ilişkin algıları benzerlik göstermektedir.

Yönetici boyutu ile kıdem yılı değisskeni: Katılımcıların kıdem yılı değişkeni ile örgütsel sessizliğin yönetici boyutu arasındaki ilişkiye ilişkin analiz sonuçları Tablo 9'da görüldüğü gibidir.

Tablo 9. Yönetici boyutu ile kıdem yılı değişkeni arasındaki ilişki

\begin{tabular}{|c|c|c|c|c|c|c|c|c|}
\hline Alt Boyut & $\bar{X}$ & $S$ & $\begin{array}{l}\text { Varyansın } \\
\text { Kaynağı }\end{array}$ & $\begin{array}{l}\text { Kareler } \\
\text { Toplamı }\end{array}$ & sd & $\begin{array}{l}\text { Kareler } \\
\text { Ortalaması }\end{array}$ & $\mathrm{F}$ & $\mathrm{p}$ \\
\hline $1-8$ yil & 3,77 & 0,53 & Gruplar Arası & 0,98 & 2 & 0,49 & \multirow{3}{*}{1,602} & \multirow{3}{*}{0,20} \\
\hline 9-17 yil & 3,76 & 0,54 & Grup İçi & 76,43 & 249 & 0,30 & & \\
\hline 17 yıl ve üzeri & 3,60 & 0,61 & Toplam & 77,42 & 251 & & & \\
\hline
\end{tabular}

Tablo 9'da yer alan sonuçlara göre 0,05 anlamlılık düzeyinde katılımcıların kıdem yılı değişkeni ile örgütsel sessizliğin yönetici boyutu arasında anlamlı bir farklılık $(\mathrm{F}=1,602 ; \mathrm{p}=0,20)$ bulunmamaktadır. Yani kathlımcların kıdem yılı fark etmeksizin yönetici boyutuna ilişkin algıları benzerlik göstermektedir. 
Yönetici boyutu ile mevcut okuldaki çalışma süresi değişkeni: Katılımcıların mevcut okuldaki çalışma süreleri değişkeni ile örgütsel sessizliğin yönetici boyutu arasındaki ilişkiye ilişkin analiz sonuçları Tablo 10'da görüldüğü gibidir.

Tablo 10. Yönetici boyutu ile mevcut okuldaki çalışma süresi değişkeni arasındaki ilişki

\begin{tabular}{|c|c|c|c|c|c|c|c|c|}
\hline Alt Boyut & $\bar{X}$ & $S$ & $\begin{array}{l}\text { Varyansın } \\
\text { Kaynağ1 }\end{array}$ & $\begin{array}{l}\text { Kareler } \\
\text { Toplamı }\end{array}$ & sd & $\begin{array}{l}\text { Kareler } \\
\text { Ortalaması }\end{array}$ & $\mathrm{F}$ & $\mathrm{p}$ \\
\hline $1-8$ yil & 3,73 & 0,54 & Gruplar Arası & 0,47 & 2 & 0,23 & \multirow{3}{*}{0,771} & \multirow{3}{*}{0,46} \\
\hline 9-17 yıl & 3,84 & 0,60 & Grup İçi & 76,94 & 249 & 0,30 & & \\
\hline 17 yıl ve üzeri & 3,56 & 0,78 & Toplam & 77,42 & 251 & & & \\
\hline
\end{tabular}

Tablo 10 'da yer alan sonuçlara göre 0,05 anlamlılık düzeyinde katılımc1ların mevcut okuldaki çalışma süresi değişkeni ile örgütsel sessizliğin yönetici boyutu arasında anlamlı bir farklılık ( $\mathrm{F}=0,771 ; \mathrm{p}=0,46)$ bulunmamaktadır. Yani katılımcıların mevcut okuldaki çalışma süreleri fark etmeksizin yönetici boyutuna ilişkin algıları benzerlik göstermektedir.

\section{Katılımcılarn Demografik Özelliklerine Göre Örgütsel Sessizlikte Öğretmen boyutu Hakkındaki Görüşleri}

Araştırma ölçeğinde yer alan örgütsel sessizliğin öğretmen boyutu 11 maddeyi kapsamaktadır. Bu maddelerin frekans, ortalama ve standart sapma dağılımları Tablo 11'te görüldüğü gibidir.

Tablo 11. Öğretmen boyutu maddelerine ait ortalamalar ve standart sapmalar

\begin{tabular}{llcc}
\hline No & Madde & $\bar{X}$ & $\mathrm{~S}$ \\
\hline 1 & Öğretmenler yöneticilerinin eksikliklerini bilmelerine rağmen bu durumu dile getirmezler. & 3,08 & 1,00 \\
\hline 2 & $\begin{array}{l}\text { Öğretmenler görüşlerini ifade ettikleri için yöneticilerden ve } \\
\text { meslektaşlarından olumsuz tepki alırlar. }\end{array}$ & 2,83 & 1,03 \\
\hline 5 & $\begin{array}{l}\text { Okulumuzda bulunan yöneticiler, öğretmenlerin yeni uygulamalar } \\
\text { konusundaki görüşlerini almaya açlk değildirler. }\end{array}$ & 2,51 & 1,03 \\
\hline 9 & Öğretmenler belirli konular hakkında konuşmaktan kaçınırlar. & 3,28 & 1,03 \\
\hline 15 & $\begin{array}{l}\text { Okul yöneticilerinin öğretmenlere adil davranmaması, öğretmenlerin } \\
\text { görüşlerini açılamalarına engel olmaktadır. }\end{array}$ & 3,21 & 1,07 \\
\hline 16 & Okul yöneticileri öğretmenlerin görüşlerini saygı ile karşılar. & 3,39 & 0,94 \\
\hline 25 & Öğretmenlerin olay ve durumlar karşısında sessiz kalmaları, gizli bir muhalefetin göstergesidir. & 3,17 & 1,02 \\
\hline 26 & Öğretmenler dışlanacakları endişesiyle duygu ve düşüncelerini dile getirmezler. & 2,94 & 1,03 \\
\hline 27 & Öğretmenler duygu ve düşüncelerini açılladıkları zaman güvende olmadıklarını hissederler. & 2,82 & 1,05 \\
\hline 29 & $\begin{array}{l}\text { Öğretmenler sorun çıarıcı ve şikâyetçi görünmek istemediklerinden, } \\
\text { olaylar ve durumlar karşısında sessiz kalmayı tercih ederler. }\end{array}$ & 3,26 & 1,00 \\
\hline 30 & Ö̆ğretmenler okulda karşlaştıkları sorunları dile getirmekten kaçınılar. & 2,90 & 1,01 \\
\hline & Genel Ortalama & 3,03 & 0,59 \\
\hline & & &
\end{tabular}


Tablo 11'de bakıldığında örgütsel sessizliğin öğretmen boyutunun genel ortalamasının 3,03 ve standart sapmanın 0,59 olduğu görülmektedir. Bu sonuca göre katılımcıların öğretmen boyutuna bağlı örgütsel sessizlik alg1 düzeylerinin ortalamanın üzerinde olduğu görülmektedir.

Bu boyutu oluşturan maddelerin tek tek ortalamaları ele alındığında en düşük ortalamaya sahip olan madde 5. maddedir. Bu maddenin ortalaması 2,51olarak hesaplanmıştır. Bu sonuca göre araştırmaya katılan öğretmenler yöneticilerin yeni uygulamalar konusunda görüşlerini alıp almayacakları konusunda bir fikir edinemedikleri söylenebilir. En yüksek ortalamaya sahip madde ise 3,39 ile 16. maddedir. Öğretmenler düşünce ve görüşlerinin yöneticiler tarafından saygıyla karşılanacağını düşünmektedirler. Ortalaması 3,28 olan 9 madde ile 3,26 olan 29. madde incelendiğinde öğretmenlerin çeşitli konuları konuşmaktan kaçındığı ve sorun çıkaran ve şikâyetçi bir kişi gibi görünmemek amacıyla sessiz kalmayı tercih ettikleri söylenebilir.

Öğretmen boyutu ile cinsiyet değişkeni: Katılımclların cinsiyet değişkeni ile örgütsel sessizliğin öğretmen boyutu arasındaki ilişkiye ilişkin analiz sonuçları Tablo 12'de görüldüğü gibidir.

Tablo 12. Öğretmen boyutu ile cinsiyet değişkeni arasındaki ilişki

\begin{tabular}{llllll}
\hline Cinsiyet & $\mathrm{N}$ & $\bar{X}$ & $\mathrm{~S}$ & $\mathrm{t}$ & $\mathrm{p}$ \\
\cline { 1 - 4 } Kadın & 116 & 3,03 & 0,58 & \multirow{2}{*}{1,071} & \multirow{2}{*}{0,28} \\
\cline { 1 - 5 } Erkek & 136 & 3,03 & 0,61 & & \\
\hline
\end{tabular}

Tablo 12'de yer alan sonuçlara göre katılımcıların cinsiyet değişkeni ile örgütsel sessizliğin öğretmen boyutu arasında 0,05 anlamlılık düzeyinde anlamlı bir farklılık $(\mathrm{t}=1,071 ; \mathrm{p}=0,28)$ bulunmamaktadır. Yani katılımciları gerek kadın gerek erkek öğretmen boyutuna ilişkin algıları benzerlik göstermektedir.

Öğretmen boyutu ile medeni durum değişkeni: Katılımclların medeni durum değişkeni ile örgütsel sessizliğin öğretmen boyutu arasındaki ilişkiye ilişkin analiz sonuçları Tablo 13'de görüldügüü gibidir.

Tablo 13. Öğretmen boyutu ile medeni durum değişkeni arasındaki ilişki

\begin{tabular}{llllll}
\hline Medeni Durum & $\mathrm{N}$ & $\bar{X}$ & $\mathrm{~S}$ & $\mathrm{t}$ & $\mathrm{p}$ \\
\hline Evli & 218 & 3,04 & 0,60 & \multirow{2}{*}{0,754} & \multirow{2}{*}{0,91} \\
\hline Bekâr & 34 & 2,96 & 0,58 & & \\
\hline
\end{tabular}


Tablo 13'de yer alan sonuçlara göre katılımcların medeni durum değişkeni ile örgütsel sessizliğin öğretmen boyutu arasında 0,05 anlamlılık düzeyinde anlamlı bir farklılık $(\mathrm{t}=0,754 ; \mathrm{p}=0,91)$ bulunmamaktadır. Yani katılımclları medeni durumu fark etmeksizin öğretmen boyutuna ilişkin algıları benzerlik göstermektedir.

Öğretmen boyutu ile branş değişkeni: Katılımcıların branş değişkeni ile örgütsel sessizliğin öğretmen boyutu arasındaki ilişkiye ilişkin analiz sonuçlarn Tablo 14'de görüldügüü gibidir.

Tablo 14. Öğretmen boyutu ile branş değişkeni arasındaki ilişki

\begin{tabular}{|c|c|c|c|c|c|c|c|c|}
\hline Alt Boyut & $\bar{X}$ & $S$ & $\begin{array}{l}\text { Varyansın } \\
\text { Kaynağ1 }\end{array}$ & $\begin{array}{l}\text { Kareler } \\
\text { Toplamı }\end{array}$ & $\mathrm{sd}$ & $\begin{array}{l}\text { Kareler } \\
\text { Ort. }\end{array}$ & $\mathrm{F}$ & $\mathrm{p}$ \\
\hline Türkçe & 3,23 & 0,59 & \multirow{4}{*}{ Gruplar Arası } & \multirow{4}{*}{8,08} & \multirow{4}{*}{11} & \multirow{4}{*}{0,73} & \multirow{12}{*}{2,147} & \multirow{12}{*}{0,018} \\
\hline Matematik & 2,98 & 0,45 & & & & & & \\
\hline Fen ve Teknoloji & 3,25 & 0,71 & & & & & & \\
\hline Sosyal Bilgiler & 2,84 & 0,48 & & & & & & \\
\hline İngilizce & 3,01 & 0,68 & \multirow{4}{*}{ Grup İçi } & \multirow{4}{*}{82,16} & \multirow{4}{*}{240} & \multirow{4}{*}{0,34} & & \\
\hline Din Kültürü ve Ahlak & 2,72 & 0,50 & & & & & & \\
\hline Görsel Sanatlar & 2,91 & 0,31 & & & & & & \\
\hline Müzik & 3,22 & 0,56 & & & & & & \\
\hline Beden Eğitimi & 2,83 & 0,70 & \multirow{4}{*}{ Toplam } & \multirow{4}{*}{90,24} & \multirow{4}{*}{251} & & & \\
\hline Teknoloji ve Tasarım & 3,08 & 0,60 & & & & & & \\
\hline Bilişim Teknolojileri & 2,90 & 0,47 & & & & & & \\
\hline Rehber & 2,83 & 0,48 & & & & & & \\
\hline
\end{tabular}

Tablo 14'de yer alan sonuçlara göre 0,05 anlamlılık düzeyinde katılımc1ların branş değişkeni ile örgütsel sessizliğin yönetici öğretmen arasında anlamlı bir farklılık $(\mathrm{F}=2,147 ; \mathrm{p}=0,018)$ belirlenmiştir. Hangi branşlar arasında farklılık olduğunun belirlenmesi amacıyla tukey testi yapılmıştır. Elde edilen sonuçlar Tablo 15'de görüldüğü gibidir.

Tablo 15. Öğretmen boyutu algısı farklı çıkan branşlar

\begin{tabular}{lrlrlll}
\hline Branş & $\bar{X}$ & Farklı Çıkan Branşlar & $\bar{X}$ & Fark & S & $\mathrm{p}$ \\
\hline \multirow{2}{*}{$\begin{array}{l}\text { Din Kültürü ve } \\
\text { Ahlak Bilgisi }\end{array}$} & \multirow{2}{*}{2,72} & Türkçe & 3,23 & $-0,51$ & 0,15 & 0,037 \\
\cline { 2 - 7 } & & Fen ve Teknoloji & 3,25 & $-0,53$ & 0,15 & 0,038 \\
\hline
\end{tabular}

Tablo 15'de yer alan sonuçlar incelendiğinde 0,05 anlamlılık düzeyinde Din Kültürü ve Ahlak Bilgisi branşındaki öğretmenler ile Türkçe $(p=0,037)$ ve Fen ve Teknoloji $(p=0,038)$ branşındakilerin öğretmen boyutu algısı arasında anlamlı bir farklılık bulunmaktadır. Bu branşların ortalamaları dikka- 
te alındığında Türkçe $(3,23)$ ve Fen ve Teknoloji $(3,25)$ branşındakilerin Din Kültürü ve Ahlak Bilgisi $(2,72)$ branşındaki öğretmenlere göre öğretmen boyutu algısının daha yüksek olduğu görülmektedir.

Öğretmen boyutu ile kıdem yılı değişkeni: Katılımcıların kıdem yılı değişkeni ile örgütsel sessizliğin öğretmen boyutu arasındaki ilişkiye ilişkin analiz sonuçları Tablo 16'da görüldüğü gibidir.

Tablo 16. Öğretmen boyutu ile kıdem yılı değişkeni arasındaki ilişki

\begin{tabular}{|c|c|c|c|c|c|c|c|c|}
\hline Alt Boyut & $\bar{X}$ & $\mathrm{~S}$ & Varyansın Kaynağı & KarelerToplamı & sd & Kareler Ortalaması & $\mathrm{F}$ & $\mathrm{p}$ \\
\hline $1-8$ yıl & 2,94 & 0,54 & Gruplar Arası & 1,75 & 2 & 0,87 & \multirow{3}{*}{2,464} & \multirow{3}{*}{0,08} \\
\hline $9-17$ yıl & 3,12 & 0,60 & Grup İçi & 88,49 & 249 & 0,35 & & \\
\hline 17 yll ve üzeri & 2,97 & 0,65 & Toplam & 90,24 & 251 & & & \\
\hline
\end{tabular}

Tablo 16' da yer alan sonuçlara göre 0,05 anlamlılık düzeyinde katılımc1ların kıdem yılı değişkeni ile örgütsel sessizliğin öğretmen boyutu arasında anlamlı bir farklılık $(\mathrm{F}=2,464 ; \mathrm{p}=0,08)$ bulunmamaktadır. Yani katilımcların kıdem yılı fark etmeksizin öğretmen boyutuna ilişkin algıları benzerlik göstermektedir.

Öğretmen boyutu ile mevcut okuldaki çalışma süresi değişkeni: Katılımcıların mevcut okuldaki çalışma süreleri değişkeni ile örgütsel sessizliğin öğretmen boyutu arasındaki ilişkiye ilişkin analiz sonuçları Tablo 17'de görüldüğü gibidir.

Tablo 17. Öğretmen boyutu ile mevcut okuldaki çalışma süresi değişkeni arasındaki ilişki

\begin{tabular}{|c|c|c|c|c|c|c|c|c|}
\hline Alt Boyut & $\bar{X}$ & $\mathrm{~S}$ & $\begin{array}{l}\text { Varyansın } \\
\text { Kaynağı }\end{array}$ & $\begin{array}{l}\text { Kareler } \\
\text { Toplamı }\end{array}$ & sd & $\begin{array}{l}\text { Kareler } \\
\text { Ortalaması } \\
\end{array}$ & $\mathrm{F}$ & $\mathrm{p}$ \\
\hline $1-8$ yll & 3,02 & 0,60 & Gruplar Arası & 0,96 & 2 & 0,48 & \multirow{3}{*}{1,344} & \multirow{3}{*}{0,26} \\
\hline 9-17 yil & 3,20 & 0,56 & Grup İçi & 89,28 & 249 & 0,35 & & \\
\hline 17 yıl ve üzeri & 2,84 & 0,38 & Toplam & 90,24 & 251 & & & \\
\hline
\end{tabular}

Tablo 17'de yer alan sonuçlara göre 0,05 anlamlılık düzeyinde katılımc1ların mevcut okuldaki çalışma süresi değişkeni ile öğretmen boyutu arasında anlamlı bir farklılık ( $F=1,344 ; \mathrm{p}=0,26)$ bulunmamaktadır. Yani katılımciların mevcut okuldaki çalışma süreleri fark etmeksizin öğretmen boyutuna ilişkin algıları benzerlik göstermektedir. 


\section{Katılımcılarn Demografik Özelliklerine Göre Örgütsel Sessizlikte Ortam boyutu Hakkındaki Görüşleri}

Araştırma ölçeğinde yer alan örgütsel sessizliğin ortam boyutu 6 maddeden oluşmaktadır. Bu maddelerin frekans, ortalama ve standart sapma dağılımları Tablo 18'de görüldüğ ü gibidir.

Tablo 18. Ortam boyutu maddelerine ait ortalamalar ve standart sapmalar

\begin{tabular}{llcc}
\hline No & Madde & $\bar{X}$ & $\mathrm{~S}$ \\
\hline 8 & Öğretmenler güç durumlarda konuşmaktan çok, susmayı tercih ederler. & 3,14 & 1,10 \\
\hline 11 & $\begin{array}{l}\text { Öğretmenlerin duygu ve düşüncelerini açılayamaması } \\
\text { kendilerinde özgüven eksikliği doğurur. }\end{array}$ & 3,62 & 0,95 \\
\hline 12 & $\begin{array}{l}\text { Öğretmenlerin duygu ve düşüncelerini açıça ifade } \\
\text { edememesi bütün olay ve durumlar hakkındadır. }\end{array}$ & 2,56 & 0,91 \\
\hline 13 & $\begin{array}{l}\text { Öğretmenlerin görüşlerini dile getirmemesi, yöneticilerin } \\
\text { otoriter davranışlarından kaynaklanmaktadır. }\end{array}$ & 2,88 & 1,00 \\
\hline 14 & $\begin{array}{l}\text { Okuldaki israf ve kayıplar öğretmenlerin kendilerini ifade } \\
\text { etmelerini engeller. }\end{array}$ & 2,56 & 0,91 \\
\hline 17 & $\begin{array}{l}\text { Öğretmenlerin bilgisizlik ve deneyimsizlik korkusu, } \\
\text { duygularını ifade etmesine engel olur. }\end{array}$ & 3,16 & 1,02 \\
\hline & Genel Ortalama & 2,98 & 0,54 \\
\hline
\end{tabular}

Tablo 18'e bakıldığında örgütsel sessizliğin ortam boyutunun genel ortalamasının 2,98 ve standart sapmanın 0,54 olduğu görülmektedir. Bu sonuca göre katılımcların ortam boyutuna bağlı örgütsel sessizlik algı düzeylerinin ortalamanın üzerinde olduğu görülmektedir.

Bu boyutu oluşturan maddelerin tek tek ortalamaları ele alındığında 12. ve 14. maddeler en düşük ortalamaya sahiptirler. Bu maddelerin ortalaması 2,56 olarak hesaplanmıştır. Katılımcılar öğretmenlerin görüşlerini tüm olaylar için dile getirmediği ve okullarda yaşanan israfın öğretmenlerin kendini ifade edememelerinden kaynaklandığ 1 fikrini tam olarak desteklemedikleri söylenebilir. En yüksek ortalamaya sahip madde ise 3,62 ile 11. maddedir. Katılımcılar fikirlerini beyan edemeyen öğretmenlerde özgüven eksikliği olacağını düşünmektedirler. Ortalaması 3,16 olan 17. madde ele alındığında öğretmenlerin bilgi ve deneyim eksikliği korkusuyla öğretmenlerin sessizliği tercih ettiği söylenebilir.

Ortam boyutu ile cinsiyet değişkeni: Katılımcların cinsiyet değişkeni ile örgütsel sessizliğin ortam boyutu arasındaki ilişkiye ilişkin analiz sonuçları Tablo 19'da görüldüğü gibidir. 
Tablo 19. Ortam boyutu ile cinsiyet değişkeni arasındaki ilişki

\begin{tabular}{llllll}
\hline Cinsiyet & $\mathrm{N}$ & $\bar{X}$ & $\mathrm{~S}$ & $\mathrm{t}$ & $\mathrm{p}$ \\
\hline Kadın & 116 & 3,02 & 0,58 & \multirow{2}{*}{1,071} & \multirow{2}{*}{0,28} \\
\hline Erkek & 136 & 2,95 & 0,51 & & \\
\hline
\end{tabular}

Tablo 19'da yer alan sonuçlara göre katılımcıların cinsiyet değişkeni ile örgütsel sessizliğin ortam boyutu arasında 0,05 anlamlılık düzeyinde anlamlı bir farklılık $(t=1,071 ; p=0,28)$ bulunmamaktadır. Gerek kadın gerek erkek katılımcıların ortam boyutuna ilişkin algıları benzerlik göstermektedir.

Ortam boyutu ile medeni durum değişkeni: Katılımcların medeni durum değişkeni ile örgütsel sessizliğin ortam boyutu arasındaki ilişkiye ilişkin analiz sonuçları Tablo 20'de görüldüğü gibidir.

Tablo 20. Ortam boyutu ile medeni durum değişkeni arasındaki ilişki

\begin{tabular}{llllll}
\hline Medeni durum & $\mathrm{N}$ & $\bar{X}$ & $\mathrm{~S}$ & $\mathrm{t}$ & $\mathrm{p}$ \\
\hline Evli & 218 & 2,98 & 0,53 & \multirow{2}{*}{0,110} & \multirow{2}{*}{0,91} \\
\cline { 1 - 5 } Bekâr & 34 & 2,97 & 0,65 & & \\
\hline
\end{tabular}

Tablo 20'de yer alan sonuçlara göre katılımcların medeni durum değişkeni ile örgütsel sessizliğin ortam boyutu arasında 0,05 anlamlılık düzeyinde anlamlı bir farklılık $(t=0,110 ; p=0,91)$ bulunmamaktadır. Yani katılımcıların medeni durumu fark etmeksizin ortam boyutuna ilişkin algıları benzerlik göstermektedir.

Ortam boyutu ile branş değişkeni: Katılımcların branş değişkeni ile örgütsel sessizliğin ortam boyutu arasındaki ilişkiye ilişkin analiz sonuçları Tablo 21'de görüldüğü gibidir.

Tablo 21. Ortam boyutu ile branş değişkeni arasındaki ilişki

\begin{tabular}{|c|c|c|c|c|c|c|c|c|}
\hline Alt Boyut & $\bar{X}$ & $\mathrm{~S}$ & Varyansın Kaynağı & Kareler Toplamı & $\mathrm{sd}$ & Kareler Ort. & $\mathrm{F}$ & $\mathrm{p}$ \\
\hline Türkçe & 3,07 & 0,54 & \multirow{4}{*}{ Gruplar Arası } & \multirow{4}{*}{3,06} & \multirow{4}{*}{11} & \multirow{4}{*}{0,27} & \multirow{12}{*}{0,919} & \multirow{12}{*}{0,52} \\
\hline Matematik & 3,03 & 0,56 & & & & & & \\
\hline Fen ve Teknoloji & 3,08 & 0,58 & & & & & & \\
\hline Sosyal Bilgiler & 2,94 & 0,37 & & & & & & \\
\hline İngilizce & 3,02 & 0,68 & \multirow{4}{*}{ Grup İçi } & \multirow{4}{*}{72,67} & \multirow{4}{*}{240} & \multirow{4}{*}{0,30} & & \\
\hline Din Kültürü ve Ahlak & 2,78 & 0,63 & & & & & & \\
\hline Görsel Sanatlar & 3,00 & 0,49 & & & & & & \\
\hline Müzik & 2,91 & 0,29 & & & & & & \\
\hline Beden Eğitimi & 2,76 & 0,45 & \multirow{4}{*}{ Toplam } & \multirow{4}{*}{75,73} & \multirow{4}{*}{251} & & & \\
\hline Teknoloji ve Tasarım & 2,80 & 0,44 & & & & & & \\
\hline Bilişim Teknolojileri & 3,05 & 0,34 & & & & & & \\
\hline Rehber & 2,96 & 0,38 & & & & & & \\
\hline
\end{tabular}


Tablo 21'de yer alan sonuçlara göre 0,05 anlamlllık düzeyinde katılımc1ların branş değişkeni ile örgütsel sessizliğin ortam boyutu arasında anlamlı bir farklılık $(\mathrm{F}=0,919 ; \mathrm{p}=0,52)$ bulunmamaktadır. Yani katılımcıların branşları fark etmeksizin ortam boyutuna ilişkin algıları benzerlik göstermektedir.

Ortam boyutu ile kıdem yılı değişkeni: Katılımcıların kıdem yılı değişkeni ile örgütsel sessizliğin ortam boyutu arasındaki ilişkiye ilişkin analiz sonuçları Tablo 22'de görüldüğü gibidir.

Tablo 22. Ortam boyutu ile kıdem yılı değişkeni arasındaki ilişki

\begin{tabular}{|c|c|c|c|c|c|c|c|c|}
\hline Alt Boyut & $\bar{X}$ & $S$ & $\begin{array}{l}\text { Varyansın } \\
\text { Kaynağı }\end{array}$ & $\begin{array}{l}\text { Kareler } \\
\text { Toplamı }\end{array}$ & sd & $\begin{array}{l}\text { Kareler } \\
\text { Ortalamas1 }\end{array}$ & $\mathrm{F}$ & $\mathrm{p}$ \\
\hline $1-8$ yil & 2,93 & 0,57 & Gruplar Arası & 0,76 & 2 & 0,38 & \multirow{3}{*}{1,274} & \multirow{3}{*}{0,28} \\
\hline 9-17 y1l & 3,04 & 0,51 & Grup İçi & 74,96 & 249 & 0,30 & & \\
\hline 17 yıl ve üzeri & 2,92 & 0,58 & Toplam & 75,73 & 251 & & & \\
\hline
\end{tabular}

Tablo 22'de yer alan sonuçlara göre 0,05 anlamlılık düzeyinde katılımclların kıdem yılı değişkeni ile örgütsel sessizliğin ortam boyutu arasında anlamlı bir farklılık $(\mathrm{F}=1,274 ; \mathrm{p}=0,28)$ bulunmamaktadır. Yani katılımcıların kıdem yılı fark etmeksizin ortam boyutuna ilişkin algıları benzerlik göstermektedir.

Ortam boyutu ile mevcut okuldaki çalışma süresi değişkeni: Katılımcıların mevcut okuldaki çalısma süreleri değişkeni ile örgütsel sessizliğin ortam boyutu arasındaki ilişkiye ilişkin analiz sonuçları Tablo 23'de görüldüğü gibidir.

Tablo 23. Ortam boyutu ile mevcut okuldaki çalışma süresi değişkeni arasındaki ilişki

\begin{tabular}{|c|c|c|c|c|c|c|c|c|}
\hline Alt Boyut & $\bar{X}$ & $\mathrm{~S}$ & $\begin{array}{l}\text { Varyansın } \\
\text { Kaynağı }\end{array}$ & $\begin{array}{l}\text { Kareler } \\
\text { Toplamı }\end{array}$ & $\mathrm{sd}$ & $\begin{array}{l}\text { Kareler } \\
\text { Ortalaması }\end{array}$ & $\mathrm{F}$ & $\mathrm{p}$ \\
\hline $1-8$ yil & 2,96 & 0,54 & Gruplar Arası & 0,93 & 2 & 0,46 & \multirow{3}{*}{1,548} & \multirow{3}{*}{0,21} \\
\hline 9-17 yıl & 3,11 & 0,55 & Grup İçi & 74,80 & 249 & 0,30 & & \\
\hline 17 yll ve üzeri & 3,25 & 0,59 & Toplam & 75,73 & 251 & & & \\
\hline
\end{tabular}

Tablo 23'de yer alan sonuçlara göre 0,05 anlamlılık düzeyinde katılımc1ların mevcut okuldaki çalışma süresi değişkeni ile örgütsel sessizliğin ortam boyutu arasında anlamlı bir farklılık ( $\mathrm{F}=1,548$; $\mathrm{p}=0,21)$ bulunmamaktadır. Yani katılımcıların mevcut okuldaki çalışma süreleri fark etmeksizin ortam boyutuna ilişkin algıları benzerlik göstermektedir. 


\section{Sonuç ve Tartışma}

Araştırmada kullanılan örgütsel sessizlik ölçeğinin genel ortalamasına bakıldığında, bu sonucun ortalamanın üzerinde olduğu, ancak ortalamaya yakın bir düzeyde olduğu söylenebilir. Standart sapma değeride katılımc1ların cevaplarının birbirine yakın olduğunu göstermektedir. Bu sonuca göre öğretmenlerin okullarda yaşadıkları olaylar ve karşılaştıkları durumlar karşısında sessiz kalmaya yöneldikleri, düşüncelerini ve yaşadıkları sorunları rahatlıkla ifade edemedikleri söylenebilir. Okullardaki işleyişe ilişkin konularda öğretmenlerin fikir beyan etmekten kaçınıyor olmaları olumsuz bir durum olarak değerlendirilebilir. Literatürde öğretmen görüşlerine dayalı olarak yapılan çalışmalarda (Gökçe, 2013; Nartgün ve Kartal, 2013; Demirtaş, Özdemir ve Küçük, 2016; Aydın, 2016; Potuk, 2017; Moçosoğlo ve Kaya, 2018; Demirtaş ve Nacar, 2018; Özdemir, Orhan ve Özkayran, 2018; Durmuş, 2019; Demir ve Cömert, 2019; Demirtaş ve Küçük, 2019; Göven ve Şentürk, 2019) öğretmenlerin örgütsel sessizlik algılarının genel olarak orta düzeyde olduğu görülmektedir. Bu sonuçlar araştırma bulgularını destekler niteliktedir. Ancak Önder (2017) araşttrmasında öğretmenlerin örgütsel sessizlik algısını düşük düzeyde olduğu sonucuna ulaşmıştır. Önder (2017) bu bulguyu, ortaöğretim okullarında görev yapan öğretmenlerin gelişen olay ve durumlar karşısında sessiz kalmadıkları, duygu ve düşüncelerini rahatça ifade ettikleri şeklinde yorumlamıştır. Ayrıca bu durumun nedenini, öğretmenlerin kamu çalışanı olarak işlerini kaybetme riski olmadığı ve okul örgütünün kendine özgü özelliklerinin olabileceği şeklinde açıklamıştır.

Literatürde, örgütsel sessizlik ile diğer örgütsel davranış kapsamına giren kavramlarla ilişkisel çalışmalar yapıldığı görülmektedir. Bu çalışmalar da, bu araştırma kapsamında bahsedildiği üzere, örgütsel sessizliğin örgüt ortamına zarar verdiğini göstermektedir. Özdemir, Orhan ve Özkayran (2018) çalışmasında örgütsel sessizlik ve sinizm arasında pozitif yönlü; Moçosoğlo ve Kaya (2018) örgütsel sessizlik ve örgütsel mutluluk arasında negatif yönlü; Önder (2017), örgütsel sessizlik ile örgütsel adalet ve örgütsel bağllık arasında negatif yönlü; Demirtaş, Özdemir ve Küçük (2016) örgütsel sessizlik ile bürokratik yapı ve örgütsel sinizm arasında pozitif yönlü; Aydın (2016), örgütsel sessizlik ile okul yönetiminde kayırmacılık arasında pozitif yönlü ilişkiler saptamışlardır. Bu çalışmalarda gösteriyor ki okullarda örgütsel sessizlik arttıkça sinizm, bürokratik yapı algısı, okul yönetiminde 
kayırmacllık artmakta buna karşın örgütsel mutluluk, örgütsel adalet ve örgütsel bağlllık azalmaktadır. Bu bulgular, örgütsel sessizliğin örgüt yapısına zarar verdiği göstermektedir. Ancak öğretmen algılarına göre Demirtaş ve Nacar (2018)' ın iş doyumu ile örgütsel sessizlik arasında Göven ve Şentürk (2019)'ün örgütsel bağlllık ile örgütsel sessizlik arasında Durmuş (2019)'un örgütsel adalet ve örgütsel sessizlik arasında anlamlı bir ilişki olmadığı yönünde elde ettikleri bulgular bu araştırmada kullanılan söylemleri desteklememektedir. Belki de bu konuda ortaya çıkan en ilginç bulgu Balyer ve Çetindere (2019)'nin araştırmasına dayanmaktadır. Bu araştırmaya göre öğretmenlerin sessizlik düzeyleri artarken, motivasyon düzeyleri de artmaktadır. Beklenenin tam tersi bu durum araştırmada, öğretmenlerin örgütsel sessizliğin artmasına bağlı olarak kendilerini koruma yönünde motivasyonlarını arttırabileceği şeklinde açıklanmaktadır.

Ölçeğin alt faktörlerine ilişkin öğretmen algılarına bakıldığında yönetici, öğretmen ve ortam boyutlarında öğretmenlerin algilarının ortalamanın üstünde olduğu görülmektedir. Bu bağlamda öğretmenlerin, yönetici konumunda olan kişilerin tutumları ve davranışları nedeniyle ve düşüncelerini dile getirdiklerinde karşılaşabilecekleri olumsuz geribildirimleri düşünerek sessiz kalmayı tercih edebilecekleri; öğretmenlerin meslektaşlarından gelebilecek olumsuz eleştiriler, yaşanabilecek bir dışlanma hali ya da kişisel olarak bilgi ve tecrübelerinin yetersiz olması sebebiyle sessiz kalabilecekleri; öğretmenlerin literatürde sessizliğin örgütsel nedenleri olarak kabul edilen örgüt kültürü ve iklimi, örgütsel adalet ve sosyalizasyon gibi çalıştıkları ortamla ilgili nedenlerle sessiz kalabilecekleri söylenebilir. Çalışmasında aynı ölçeği kullanan Kahveci ve Demirtaş (2013) yönetici boyutunda "katıllyorum" ögrretmen ve ortam boyutunda "orta düzeyde katıllyorum" sonuçlarına ulaşmıştır. Literatürde farklı örgütsel sessizlik ölçekleri de kullanılmıştır. Öğretmen algılarına göre Sarıdede (2019) sadece örgüt yararına sessizliği temsil eden ilişkisel boyutu ortalamanın üzerinde, kabullenici ve savunmacı boyutlarının ise düşük düzeyde olduğunu; Dal ve Başkan (2018) okul ortamı, sessizliğin kaynağı ve izolasyon alt boyutlarında "orta" düzeyde, duygu ve yönetici alt boyutlarında ise "yüksek" düzeyde olduğunu; Demirtaş, Özdemir ve Küçük (2016) izolasyon duygu, yönetici, okul ortamı ve sessizliğin kaynağı alt boyutlarında olmak üzere tüm boyutlara orta düzeyde olduğunu; Potuk (2017) savunma amaçlı seslilik ve sessizlik ile kabul edilen sessizlik düzeylerinin düşük, örgüt yararına seslilik ve sessizlik dü- 
zeylerinin yüksek, kabul edilen seslilik ve genel örgütsel sessizliklerinin orta düzeyde olduğunu tespit etmiştir.

Çalışmada, genel olarak örgütsel sessizliğin alt boyutları ile öğretmenlerin cinsiyet, medeni durum, branş, kıdem yılı ve mevcut okuldaki çalışma süresi değişkenleri arasında anlamlı bir farklılık bulunmamıştır. Sadece öğretmen boyutu ile katılımcların branş değişkeni arasında anlamlı bir farklılık bulunmuştur. Branşlar bazında farklılık incelendiğinde Türkçe ile Fen ve Teknoloji branşlarının Din Kültürü ve Ahlak Bilgisi branşındaki öğretmenlere göre sessizlik düzeylerinin daha yüksek olduğu sonucuna ulaşılmıştır. Benzer şekilde Kahveci ve Demirtaş (2013) branş değişkeni açısından "Dil (Türkçe ve İngilizce)" grubunda bulunan katılımclların diğer branşlarda bulunan katılımclara oranla daha fazla sessiz kaldığı sonucuna ulaşmıştır. Bunun dışında cinsiyet ve okulda çalışılan süre değişkenlerinde anlamlı farklılıklar tespit ederken yaş ve hizmet süresi değişkenlerinde anlamlı farklılıklar tespit edememişlerdir. Diğer çalışmalarda ise öğretmenlerin sessizlik düzeyleri ile Nartgün ve Kartal (2013) cinsiyet, kıdem ve kurumda çalışma süresi değişkenleri arasında anlamlı bir ilişki olmadığı; Özdemir, Orhan ve Özkayran (2018) cinsiyet, okul türü ve branş değişkenlerine göre anlamlı bir ilişki olmadığı; Sarıdede (2019) cinsiyete göre anlamlı bir ilişki olmadığı, okuldaki çalışma süresi ve kıdeme göre anlamlı bir ilişki olduğu; Demir ve Cömert (2019) cinsiyet, medeni durum, öğrenim durumu ve mesleki kıdeme göre anlamlı bir ilişki olmadığı, öğrenim durumuna göre anlamlı bir ilişki olduğu; Dal ve Baskan (2018) yaptığı okuldaki hizmet süresi, eğitim durumu ve branşa göre anlamlı bir ilişki olmadığı, cinsiyet, yaş ve mesleki kıdeme göre anlamlı bir ilişki olduğu yönünde bulgulara ulaşmışlardır. Literatürdeki bulgular incelendiğinde genel olarak örgütsel sessizlik ve öğretmenlerin sahip olduğu demografik özellikler arasında anlamlı ilişkilerin sayısının az olduğu daha çok anlamlı olmayan ilişkiler çıktığı görülmektedir. Bu çalışmada da benzer bulgulara ulaşılmıştır.

Bu araştırma kapsamında aşağıdaki önerilerde bulunulmuştur:

- Araştırma sonuçlarına göre örgütsel sessizliğe neden olan en önemli faktör yöneticilerdir. Yönetici kaynaklı örgütsel sessizliğin önene geçmek için okul yöneticilerine iletişim ve yönetim konusunda düzenli olarak hizmet içi eğitim verilebilir. Yöneticiler atanırken yönetim ve iletişim konusunda özel eğitim almış kişilere (yüksek lisans, özel sertifika 
vb.) öncelik verilebilir. Bununla birlikte öğretmenlerin yöneticilerin performansını değerlendirebileceği bir sistem geliştirilebilir.

- Öğretmenlerin dişlanma korkusu, yöneticilere güvensizlik, kültürel yapı gibi çeşitli kişisel özellikleri de örgütsel sessizliğe neden olmaktadır. Bu faktörü en aza indirmek için öğretmenlerin özellikle doğrudan kendilerini ilgilendiren konularda karara katılmalarını sağlayacak bir yönetim sistemi kurulabilir. Karara katılmaları mümkün değilse bu karar alınmadan önce öğretmenler bilgilendirilmelidir.

- Çalışılan okul ortamı da örgütsel sessizliğe neden olan bir faktördür. Örgütsel sessizliğin bir örgüt kültürü, örgütsel iklim olmasına fırsat verilmemeli ve örgütsel adalet sağlanmalıdır. Örgütsel sosyalizasyon süreci çok iyi işletilmelidir. Yönetici ve öğretmenlerin düzenli sosyal faaliyetlerle bir araya gelmeleri sağlanarak aralarında etkili bir iletişim sağlanabilir.

- Ortaokullarda görev yapan öğretmenlerin örgütsel sessizlik algılarının değerlendirmesi çalışmasının sonuçlarından hareketle araştırmacılara şu önerilerde bulunulabilir.

- Örgütsel sessizlik algısı farklı düzeydeki eğitim kurumlarında (ilkokul, lise, üniversite) araştırılabilir.

- Özel eğitim kurumlarında benzer bir araştırma yapılıp sonuçlar resmi kurumlardaki örgütsel sessizlik düzeyi ile karşılaştırılabilir. Bu araştırmanın sonuçları aynı konuda yapılacak nitel araştırmalarla karşılaştırılabilir. 


\title{
EXTENDED ABSTRACT
}

\section{Organizational Silence In Secondary Schools In The Context Of Teacher Perceptions}

\author{
Soner Doğan - Esma Karahan Çidem \\ Sivas Cumhuriyet Üniversitesi-Milli Ĕ̆itim Bakanlığ
}

Today, it is important for organizations to be productive and open to innovations in order to survive and maintain their success. The most important factor affecting the success of an organization is the work of the employees for the good of the organization. Their abilities, experience, emotions and thoughts, and commitment to their jobs are of the utmost importance for the efficiency of the organization. Therefore, organizations need to value their ideas, expectations and suggestions as well as providing opportunities for them to show themselves within the organization. In this context, it is important for the employees in these organizations not to remain silent but to express themselves in all organizational processes. However, depending on several reasons, employees opt for organizational silence and are not be able to provide benefits for the organization.

Organizational silence is a concept signifying the unwillingness of corporate employees to exert efforts that will have corporate contribution (Dyne, Ang and Botero, 2003). Organizational silence may be defined as the fact that employees in an organization deliberately conceal their ideas, information and thoughts about their job or corporations as well as hiding their real opinions on issues concerning the organization (Morrison \& Milliken, 2000). Organizational silence contains several psychosocial factors such as threat, fear, withdrawal and defense mechanisms.

Schools are structures in which knowledge is produced, updated and developed. It is in the duty of schools to train the labor force that is necessary for the society. Institutions that train the human element, which is the most fundamental element of every social organization, should be open to continuous development and change. It is important to investigate the issue of organizational silence, which is a major impediment to change and development, and to provide solutions on the matter (Bayram, 2010). 
The present study aims to measure secondary school teachers' perception of organizational silence. It can be said that organizational silence is a major impediment to organizational development and innovation and that at the same time it leads to the incapacity to solve intraorganizational problems and a decrease in organizational commitment in employees. In this regard, identifying the perception level of teachers participating in the present study on organizational silence and providing the reasons behind silence are of the utmost importance in terms of contributing to solutions on the problem.

The relationship between dependent and independent variables was analyzed in the study. Relational scanning model was used in order to identify this relationship. Relational screening model is a research method aiming to identify whether there is a covariance between two or more variables and the level of this covariance if there is one (Karasar, 2013).

The universe of the study is composed of teachers working in secondary schools affiliated with the Ministry of National Education in Sivas city center. There are 79 secondary schools operating in Sivas city center (https://sivas.meb.gov.tr/). Using the convenience sampling method, 300 teachers working in these schools were sent a survey and 252 evaluable scales were obtained accordingly.

The survey method, one of the primary data collection techniques, was used in the study. A survey is the data collection technique that the researcher asks participants to answer in the pre-determined order and structure (Uzgören, 2012). The survey used in this study contains two parts. In the first part, demographic information about the participants was asked. The second part contains the Organizational Silence Scale. There are 30 items on this scale developed by Kahveci and Demirtaş (2013).

SPSS 22 program was used in data analysis. Firstly, frequency and percentage distributions of demographic features were calculated. Cronbach's Alpha value was calculated for the reliability of the scale. Moreover, before analyzing the differences of subscales in the study based on demographic features, Levene's test is one of the tests to be performed in order find whether variance in the dependent variable is homogeneously distributed into groups in the independent variable, that is whether there is normal distribution. Since the research data had normal distribution, parametric tests were performed in the analysis. In order to identify the relationship 
between demographic features and scale factors, t-test was used for gender and marital status variables whereas ANOVA test was used for variables such as age, branch, year of seniority and working year in the current school

The grand mean of the Organizational Silence Scale used in the study reveals that this result is above average, but close to the average. The standard deviation value demonstrates that participants' answers are close to one another. According to this result, it can be said that teachers tend to remain silent about the events and circumstances they encounter in schools and that are unable to express their thoughts and problems they face easily. The fact that teachers refrain from stating their opinions on the issues related to the functioning of schools may be considered as an adversity. It is observed that the general perception of teachers on organizational silence is at a medium level in studies based on teacher opinions in the literature (Gökçe, 2013; Nartgün and Kartal, 2013; Demirtaş, Özdemir and Küçük, 2016; Aydın, 2016; Potuk, 2017; Moçosoğlo and Kaya, 2018; Demirtaş and Nacar, 2018; Özdemir, Orhan and Özkayran, 2018; Durmuş, 2019; Demir and Cömert, 2019; Demirtaş and Küçük, 2019; Göven and Şentürk, 2019) These results support the research findings.

In the study, no significant difference was found between the subscales of organizational silence and variables such as teachers' gender, marital status, branch, year of seniority and working year in the current school. A significant difference was found only between the teacher subscale and the branch variable. When the difference was analyzed in terms of branches, it was concluded that teachers in Turkish, Science and Technology branches had higher levels of silence compared to teachers in the Religious Culture and Morel Knowledge branch. Similarly, Kahveci and Demirtaş (2013) concluded that in terms of the branch variable, participants in the "Language (Turkish and English)" group remained more silent than participants in other branches. In addition, while they found significant differences in gender and working year in the current school variables, they could not find significant differences in age and term of office variables.

\section{Kaynakça / References}

Alparslan, A. M. ve Kayalar, M. (2012). Örgütlerde sessizlik: sessizlik davranışları ve örgütsel ve bireysel etkileri. Mehmet Akif Ersoy Üniversitesi Sosyal Bilimler Enstitüsü Dergisi, 6 (1), 136-147. 
Aydın, Y. (2016). Örgütsel sessizliğin okul yönetiminde kayırmacılık ve öğretmenlerin öz yeterlik algiss ile ilişkisi. Kuram ve Uygulamada Eğitim Yönetimi, 22(2), 165-192. doi: 10.14527/kuey.2016.007

Balyer, A., ve Çetindere, E.D. (2019). Öğretmenlerin örgütsel sessizlik algıları ile motivasyonları arasındaki ilişkinin incelenmesi . YILDIZ Journal of Educational Research, 3 (2), 99-116.

Bayram, T. Y. (2010). Üniversitelerde örgütsel sessizlik. Yayımlanmamış Yüksek Lisans Tezi, Abant İzzet Baysal Üniversitesi Sosyal Bilimler Enstitüsü, Bolu.

Bağ, D. ve Ekinci, C. E. (2018). Öğretim elemanlarında örgütsel sessizlik davranışı, nedenleri ve sonuçları. Journal of Human Sciences, 15 (1), 567-580.

Bowen, F. ve Blackmon, K. (2003). Spirals of silence: the dynamic effects of diversity on organizational voice. Journal of Management Studies, 40 (6), 1393-1417.

Çakıcı, A (2007). Örgütlerde sessizlik: sessizliğin teorik temelleri ve dinamikleri. Çukurova Üniversitesi, Sosyal Bilimler Enstitüsü Dergisi, 16 (1), 145-162.

Çakıc1, A. (2008). Örgütlerde sessiz kalınan konular sessizliğin nedenleri ve algılanan sonuçları üzerine bir araştırma. Çukurova Üniversitesi Sosyal Bilimler Enstitüsü Dergisi, 17 (1), 117-134.

Çavuş, M, Develi, A ve Sarığlu, G. (2015). Mobbing ve örgütsel sessizlik: enerji sektörü çalışanları üzerine bir araştırma. İşletme ve İktisat Çalışmalan Dergisi, $3(1), 10-20$.

Dal, H. A. ve Baskan, G. (2018). Ortaöğretim kurumlarında örgütsel sessizliğe ilişkin öğretmen görüşleri. Kuram ve Uygulamada Ĕ̆itim Yönetimi, 24 (1), 45-91.

Demir, E. ve Cömert, M. (2018). Ortaokul öğretmenlerinin örgütsel sessizlik algiları. Mehmet Akif Ersoy Üniversitesi Ĕ̆itim Fakültesi Dergisi, (49), 148-165.

Demirtaş, Z. ve Küçük, Ö. (2019). Okul müdürlerinin toksik liderlik davranışları ile öğretmenlerin örgütsel sessizliği arasındaki ilişki. Pamukkale Üniversitesi Eğitim Fakültesi Dergisi,47, 41-58. doi: 10.9779/pauefd.489747

Demirtaş, Z. ve Nacar, D. (2018). Öğretmenlerin iş doyumu ve örgütsel sessizlik algıları arasındaki ilişki. Eğitim Yansımaları, 2(1), 13-23.

Demirtaş, Z., Özdemir, T. Y. ve Küçük, Ö. (2016). Okulların bürokratik yapısı, örgütsel sessizlik ve örgütsel sinizm arasındaki ilişki. Kuram ve Uygulamada Eğitim Yönetimi, 22(2), 193-216. doi: 10.14527/kuey.2016.008

Durmuş, H. G. (2019). Öğretmenlerin örgütsel adalet ve örgütsel sessizlik algilarn arasindaki ilişki. Yayımlanmamış Yüksek Lisans Tezi, Pamukkale Üniversitesi Eğitim Bilimleri Enstitüsü, Denizli. 
Dyne, L. V., Ang, S. ve Botero, I. C. (2003). Conceptualizing employee silence and employee voice as multidimensional constructs. Journal of management studies, 40 (6), 1359-1392.

Erigüç, G., Özer, Ö. Sonğur, C. ve Turaç, İ. S. (2014). Bir devlet hastanesinde hemşirelerde örgütsel sessizlik üzerine bir araştırma. Çankır Karatekin Üniversitesi İ̈BF Dergisi, 4 (2), 61-84.

Erol, G. ve Köroğlu, A. (2013). Liderlik tarzları ve örgütsel sessizlik ilişkisi: Otel işletmelerinde bir araştırma. Seyahat ve Otel Iş̧letmeciliği Dergisi, 10 (3), 45-64.

Fapohunda, T. N. (2016). Organizational silence: Predictors and consequences among university academic staff. International Journal for Research in Social Science and Humanities Research, 2 (1), 83-103.

Gencer, M. (2018). Güç merkezi oluşturma oyunlarmın örgütsel sessizlik ve örgütsel sosyalleşmeye etkisi. Yayınlanmamış Yüksek Lisans Tezi, Pamukkale Üniversitesi Sosyal Bilimler Enstitüsü, Denizli.

Gökçe, N. (2013). Lise öğretmenlerinin örgütsel sessizlik düzeyleri. Yayımlanmamış Yüksek Lisans Tezi, Maltepe Üniversitesi, Sosyal Bilimler Enstitüsü, İstanbul.

Gül, H. ve Özcan, N. (2011). Mobbing ve örgütsel sessizlik arasındaki ilişkiler: Karaman İ Özel İdaresinde görgül bir çalışma. Kahramanmaraş Sütçü İmam Üniversitesi İktisadi ve İdari Bilimler Fakültesi Dergisi, 1 (2) , 107-134.

Göven, E. K. ve Şentürk, İ. (2019). İkokullarda örgütsel sessizlik ile örgütsel bağlılık arasındaki ilişki: Eskişehir il merkezindeki ilkokullarda bir çalışma. Eskişehir Osmangazi Üniversitesi Sosyal Bilimler Dergisi, 20, 12231247.

Henriksen, K. ve Dayton, E., (2006). Organizational silence and hidden threats to patient safety. Health Services Research, 41 (4), 1539-1554.

Kahveci, G. (2010). İlköğretim okullarnnda örgütsel sessizlik ile örgütsel bă̆gllık arasındaki ilişkiler. Yayımlanmamış Yüksek Lisans Tezi, Fırat Üniversitesi, Elazı̆̆.

Kahveci, G. ve Demirtaş, Z. (2013). Okul yöneticisi ve öğretmenlerin örgütsel sessizlik algiları. Ĕ̆itim ve Bilim, 38 (167), 50-64.

Kalaycı, Ş. (2008). SPSS Uygulamalı çok değişkenli istatistik teknikleri. Ankara: Asil Yayın Dağıtım.

Karadal, H. (2011). Örgütsel sessizlik davranışı ve etkileri., Ö. Yeniçeri ve Y Demirel (Editörler). Yönetimde Birey ve Örgüt Odaklı Davranışlar. Bursa: Ekin Yayınevi, ss. 365-386.

Karasar, N. (2013). Bilimsel araştırma yöntemi. (25. baskı). Ankara: Nobel Yayın Dağıtım. 
Konakcı Göven, E. (2018). İlkokullarda örgütsel sessizlik ile örgütsel bağhllı arasindaki ilişki Eskişehir il merkezindeki ilkokullarda bir çalş̧ma. Yayımlanmamış Yüksek Lisans Tezi, Eskişehir Osmangazi Üniversitesi Eğitim Bilimleri Enstitüsü, Eskişehir.

Mercan, N. (2015). Ajzen'in planlanmış davranış teorisi bağlamında whistleblowing (bilgi ifşası). Sosyal ve Beşeri Bilimler Dergisi, 7 (2) , 1-14.

Milliken, F. J., Morrison, E. W. ve Hewlin, P. F. (2003). An exploratory study of employee silence: Issues that employees don't communicate upward and why. Journal of management studies, 40 (6), 1453-1476.

Moçoşoğlu, B. ve Kaya, A. (2018). Okul yöneticileri ve öğretmenlerin örgütsel sessizlik ile örgütsel mutluluk düzeyleri arasındaki ilişki: Şanlıurfa ili örneği. Harran Maarif Dergisi, 3(1), 52-70.

Morrison, E. W. ve Milliken, F. J. (2000). Organizational silence: A barrier to change and development in a pluralistic world. Academy of Management review, 25 (4), 706-725.

Nartgün, S. S. ve Kartal, V. (2013). Ögretmenlerin örgütsel sinizm ve örgütsel sessizlik hakkindaki görüşleri. Bartin Üniversitesi Egitim Fakültesi Dergisi, 2(2), 47.

Önder, E. (2017). Ortaöğretim okullarında örgütsel sessizliğin yordayıcısı olarak örgütsel adalet ve örgütsel bağlllk. Journal of Kirsehir Education Faculty, 18(2).669-686.

Özdemir, T. Y., Orhan, M. ve Özkayran, S.E. (2018). İlkokul ve ortaokul öğretmenlerinin örgütsel sinizm davranışları ile örgütsel sessizlik davranışları arasındaki ilişkinin incelenmesi. Atatürk Üniversitesi Kazım Karabekir Eğitim Fakültesi Dergisi, (37), 1-20.

Pallant, J. (2001). SPSS survival manual. Buckingham: Open University Press.

Pinder, C. C. ve Harlos, K. P. (2001). Employee silence: Quiescence and acquiescence as responses to perceived injustice. In K. M. Rowland and G. R. Ferris (Eds.), Research in personnel and human resources management (pp. 331-369). New York, NY: JAI Press.

Potuk, A. (2017). Mobbing davranışı, örgütsel adalet ve örgütsel sessizlik algllan arasindaki ilişki. Yayımlanmamış Yüksek Lisans Tezi, ESOGÜ, Eğitim Bilimleri Enstitüsü, Eskişehir.

Şahin, H. (2016). Örgütsel sessizlik ve çalışanlarn performansları arasındaki ilişki: İzmir ili çiğli ilçesi devlet ilkokullarna ilişkin bir araştırma. Yayınlanmamış Yüksek Lisans Tezi, Celal Bayar Üniversitesi, Manisa. 
Sarıdede, U. (2019). İlköğretim öğretmenlerinin örgütsel sessizlik düzeylerinin incelenmesi. Kuramsal Ĕ̈̆itimbilim Dergisi, 12(3), 950-961.

Türk Dil Kurumu (TDK). (2005). Türkşe Sözlük. Ankara.

Uzgören, N. (2012). Temel istatistiksel yöntemler ve SPSS uygulamalan (2. Baskı). Bursa: Ekin Basım Yayın Dağıtım.

Vakola, M. ve Bouradas, D. (2005). Antecedents and consequences of organisational silence: an empirical investigation. Employee Relations, 27(5), 441-458.

Yaman, E. ve Ruçlar, K. (2014). Örgüt kültürünün yordayıcısı olarak üniversitelerde örgütsel sessizlik. Yüksekögretim ve Bilim Dergisi, 4 (1), 36-50.

\section{Kaynakça Bilgisi / Citation Information}

Doğan, S. ve Karahan Çidem, E. (2021). Öğretmen algıları bağlamında ortaokullarda örgütsel sessizlik. OPUS-Uluslararası Toplum Araştırmaları Dergisi, 17(35), 1674-1704. DOI: 10.26466/opus.725872 